\title{
ANALYSIS OF CHIP FRAGMENTATION IN AZ91HP ALLOY MILLING WITH RESPECT TO REDUCING THE RISK OF CHIP IGNITION
}

\section{ANALIZA FRAGMENTACJI WIÓRÓW PODCZAS FREZOWANIA STOPU AZ91HP W ASPEKCIE ZMNIEJSZENIA RYZYKA ZAPŁONU*}

\begin{abstract}
Magnesium alloys are used as advanced structural materials for producing machine components for the aircraft or automotive industry. The machining of these components involves the risk of uncontrolled ignition during machining operations and production of fine-grained chip fractions causing the wear of kinematic pairs in technological machines. Given the operation of machine tools, the determination of a method for assessing risk based on determining a safe milling range and suitable operational parameters seems justified. The paper presents the results of investigations on chip fragmentation, chip mass and dimensions. Based on these parameters, we determine effective and safe regions with respect to operation of machine tools. The experiments are performed on magnesium alloy AZ91HP, one of the most widely used casting alloys.
\end{abstract}

Keywords: high-speed dry milling, magnesium alloys, safety, reliability, maintenance of machines.

\begin{abstract}
Stopy magnezu sa wykorzystywane jako nowoczesne materialy konstrukcyjne na elementy maszyn wytwarzane m.in. na potrzeby przemystu lotniczego czy motoryzacyjnego. Obróbka skrawaniem tych elementów wiąże się z ryzykiem niekontrolowanego zaptonu podczas wykonywania operacji obróbkowych oraz powstawaniem drobnoziarnistych frakcji wiórów powodujących przyspieszone zużycie węzłów kinematycznych maszyn technologicznych. Zaproponowanie oceny ryzyka związanego z wyborem zakresu, uznawanego za bezpieczny, parametrów technologicznych frezowania, wydaje się celowe ze względów eksploatacyjnych maszyn obróbkowych. W artykule przedstawiono wyniki badań fragmentacji wiórów, ich masy oraz wymiarów charakterystycznych wiórów. Istotnym wydaje się określenie (na podstawie wymienionych wskaźników) obszarów uznawanych ze efektywne a zarazem bezpieczne z punktu widzenia eksploatacji maszyn obróbkowych. Do badań wytypowano często stosowany stop magnezu, z grupy odlewniczych, AZ91HP.
\end{abstract}

Stowa kluczowe: frezowanie na sucho, stopy magnezu, bezpieczeństwo, niezawodność, eksploatacja maszyn.

\section{Introduction}

The growing demand for tools, vehicles or devices with their weight reduced as much as possible has led to the popularity of magnesium alloys which can be an alternative to other structural materials. From the point of view of machining, magnesium alloys have very good machining properties. They have low specific cutting resistance, low cutting loads and low temperatures in the cutting zone, among others. Magnesium alloys are also characterized by high strength and casting properties, high vibration damping capacity and good electromagnetic radiation shielding [23]. Owing to these properties, magnesium alloys are widely used in such spheres as the automotive industry as well as aircraft and machine design. The growing interest in applications of magnesium alloys in various spheres of life was also generated by advancements in alloy technology and production methods for magnesium products which include, among others, extensive research on special machine tools.

Assuming that maintenance is the whole of events and phenomena that occur in a given technical object (from manufacturing to disposal), it is possible to determine safe regions regarding the criterion of reliable and failure-free operation. Given the complexity of machining devices, the assessment of their operational reliability should rather be made in terms of synthesis and analysis of utility, machine reliability and life regarding optimum machining effect and the use ensuring their longest maintenance possible. When it comes to describing state-of-art technological machines (complex cases), it seems advisable to use models with a serial structure, as every machine component must remain usable [13]. The maintenance of certain devices and machines also depends on their structural parameters and their role in a production process. The operational strategy should therefore be tailored to specific devices and machines (Fig. 1) as well as their operational conditions [12].

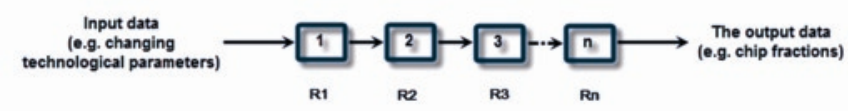

Fig. 1. Example of a reliable structure of a technical object (technological machine) in a series-based system $(R 1 \div R n-$ reliability of all elements in the series) [13]

In technical sciences, the concept of safety refers only to people (their health or life hazard), while all economic aspects pertain to reliability. The notion of reliability should be extended to cover operational safety of machine tools. Operational safety can be defined as operation which does not pose the risk of machine tool component damage. Safety is measured by the so-called "risk", which means assessing the probability of given losses in the system at a specific time

(*) Tekst artykułu w polskiej wersji językowej dostępny w elektronicznym wydaniu kwartalnika na stronie www.ein.org.pl 


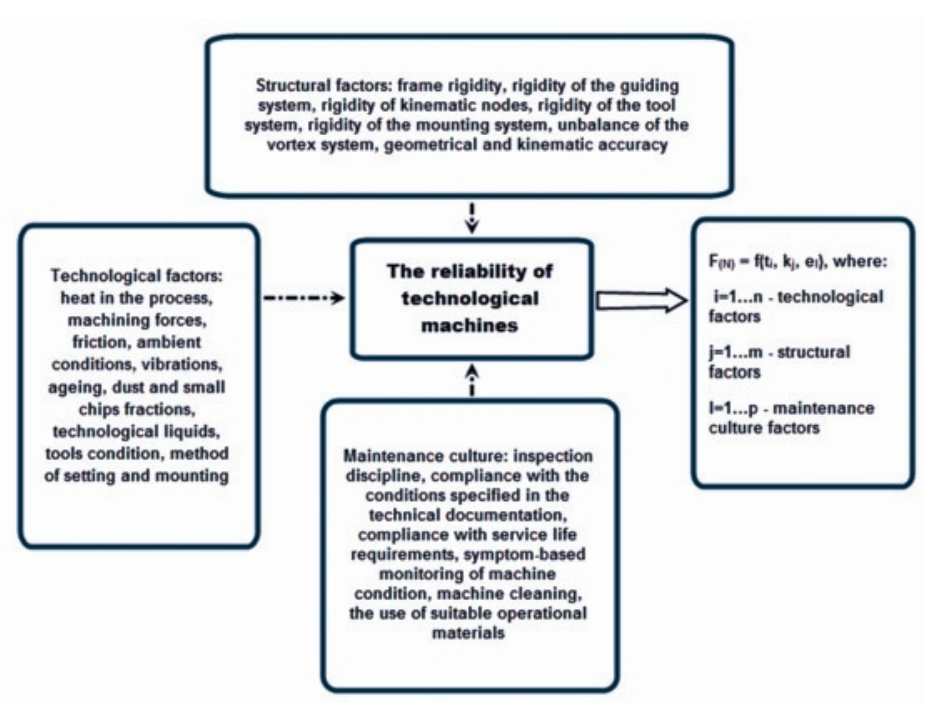

Fig. 2. Factors affecting operational reliability of a technological machine as a complex technical object

interval. There are many methods for risk assessment. Safety can be measured in terms of hazards or failure intensity [18].

A technological machine is a complex technical object. Its operational reliability depends on a number of factors, the most significant of which are given in Fig. 2. As can be observed, the "output function" is described by three main groups of factors characterizing operational reliability of technological machines. They are technological, structural and maintenance culture-related factors.

In recent years, optimization of the machining process has become the object of detailed research. Particular attention is paid to the problem of machined surface quality $[6,20]$ and surface layer analysis of machine components $[3,4]$.

The selection of tool geometry and machining parameters is a key problem in face milling. The results demonstrate that both efficiency and workpiece surface roughness in the face milling process were higher than those in the classical milling process with shank cutters. Machining times in machining by plunge milling can be reduced by even $60 \%$ compared to other machining strategies, particularly if the HSM technique is applied. This will bring substantial benefits for the technological process, leading to more effective operation of the machine as well as a longer life and higher reliability of cutting tools. One of the key criteria of technological process effectiveness is machining time. Taking this criterion into account, the best tool is one that can be operated at the highest cutting speed and feed per tooth in the assumed tool life under cut. The application of such tools requires the use of a suitable machine which can be operated at the required cutting parameters [19]. As the practice shows, tool life is also significant in the machining of high-silicon aluminium alloys (the socalled "silumins"), particularly in automated machining performed on numerically controlled machining centres. In these cases, frequent replacement of tools due to wear can cause problems connected with machine control and machined product quality. Increased tool wear in the machining of these alloys generates higher cutting loads, which has a negative effect on operational conditions of machine tools [9].

One of the most serious threats in magnesium alloy machining is self-ignition which can occur due to a sudden increase in temperature caused by e.g. tooth wear or built up edge. The temperature of magnesium ignition ranges from $480 \div 645^{\circ} \mathrm{C}[16,17]$; at higher temperatures, chips and dust ignite and burn with a light flame which is difficult to extinguish. The built up edge resulting from higher adhesion is another problematic issue which can be reduced by selecting suitable machining parameters and coatings for cutting tools. On the one hand, the low mass density of magnesium $\left(1.74 \mathrm{~g} / \mathrm{cm}^{3}\right)$ is one of its greatest advantages; on the other, it leads to formation of magnesium dust. This dust generated during machining can have a negative effect on the health of a machine-operating staff. In addition to this, fine chips and dust seriously impair the machine's operational efficiency. They can damage the machine tool if they get into its work space (guides, bearings), thereby leading to faster machine wear. Moreover, they pollute the work space of the machine as they are difficult to remove. Finally, their storage generates additional costs.

Despite these shortcomings, the interest in magnesium alloys continues unabated; there are more and more studies on optimization of magnesium alloy products in terms of machining safety and stability. Magnesium alloys are advanced innovative structural materials which are applied, among others, in the aircraft industry due to reduced operational costs. Structural components made of $\mathrm{Mg}$ alloys provide an interesting alternative to components made of polymer materials (polymers are more difficult to recycle) and $\mathrm{Al}$ alloys (higher density) $[4$, 17]. In various treatment processes, attempts are made at developing methods for chip control so as to obtain inflammable chips [2]. Partial meltings or burns on chip flanks can occur when the melting point is exceeded (for $\mathrm{Mg}$ it is about $650^{\circ} \mathrm{C}$ ) during machining. Partial meltings are often observed by scanning electron microscopy (SEM) [3] or optical microscopy [10]. Magnesium alloy chips have a characteristic structure. One side has a lamellar structure, while the other is characterized by a glossy and smooth surface. Lamellas are regular laminar structures, usually in parallel arrangement. The glossy and smooth surface is created due to contact between the chip and the tool's rake face [4].

Chip shapes can be classified according to the standard PN-ISO 3685:1996 developed with respect to turning operations. However, this classification should be considered exemplary in light of the great number of chip types that can be formed. It is therefore recommended that a classification system describing every real machining process be developed. The shape of chips also greatly depends on cutting tool geometry, states of strain and stress, or so-called "material decohesion" (separation) in the zone of chip formation [22].

The results of investigations into magnesium alloys machining reveal that with conventional machining and the application of higher cutting speeds (using popular milling machines manufactured by different producers), fragmentation of chips and increase in their average unit mass are affected to the highest degree by the feed per tooth $\mathrm{f}_{\mathrm{z}}$ and the depth of cut $\mathrm{a}_{\mathrm{p}}$. An increase in $\mathrm{f}_{\mathrm{z}}$ and a decrease in $\mathrm{a}_{\mathrm{p}}$ led to increasing the number of intermediate chip fractions, which is not desired in terms of machining safety. An excessive increase in the cutting speed $\mathrm{v}_{\mathrm{c}}$ in high-speed machining (HSM) can lead to a higher number of intermediate chip fractions [10].

The research on the machining of magnesium alloys also involved analysis of the effect of heat generated in the cutting zone. To this end, we measured chip temperature in the cutting zone, the mean temperature of tool application surface and the temperature on the tool-workpiece contact $[3,11]$. It was equally important to examine the problem of chip ignition for machining processes run at small depths of cut and the so-called ignition point of a given type of $\mathrm{Mg}$ alloy $[5,21]$. The investigation into chip ignition during machining is connected with determination of the so-called "undeformed chip thickness." For theoretical reasons, attempts are made at assessing undeformed chip thickness $[14,15]$. An increase in the cutting loads leads to an increase in the so-called "deformed chip thickness." When the undeformed chip thickness decreases, the shearing angle decreases, too, which makes the temperature in the shearing plane increase [3]. The type of produced chips (hence, the type of ignition) depends on such factors as cutting speed, depth of cut and the type (chemical composition) of a magnesium alloy. Chip ignition is hindered with increasing $\mathrm{Al}$ content, among others [1]. 
Table 1. Examples of AZ91HP alloy chip fractions on varying the depth of cut $a_{p}:$ a) $\left.a_{p}=0.5 \mathrm{~mm}, b\right) a_{p}=1.5 \mathrm{~mm}$, c) $a_{p}=3 \mathrm{~mm}$ at $v_{c}=800 \mathrm{~m} /$ $\min , f_{z}=0.05 \mathrm{~mm} /$ tooth and $\gamma=5^{\circ}$

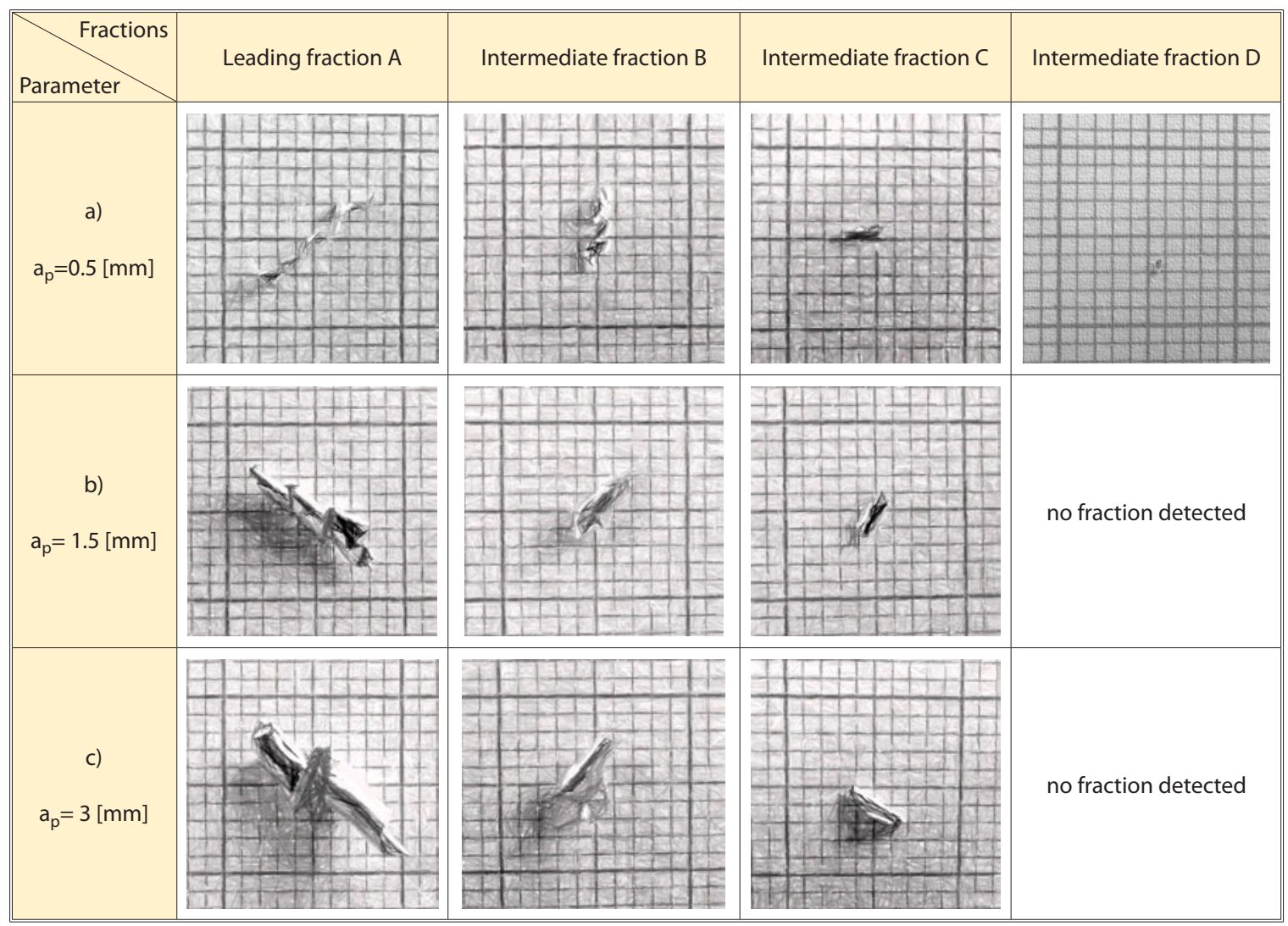

\section{Programme and experimental details}

Fig. 3 presents the plan of investigations plan followed in analysis of the investigated parameters. The first stage of analysis involved defining chip geometry, the results of which were then used to divide the chips into individual fractions (degree of fragmentation) depending on changes in the examined parameters. Next, we analyzed the unit mass of chips and their overall dimensions. The changeable parameters included: a depth of cut $\mathrm{a}_{\mathrm{p}}(0,5 ; 1,5 ; 3[\mathrm{~mm}])$, a feed per tooth $\mathrm{f}_{\mathrm{z}}(0,05 ; 0,15 ; 0,3[\mathrm{~mm} /$ tooth $])$, a cutting speed $\mathrm{v}_{\mathrm{c}}(400 ; 800 ; 1200[\mathrm{~m} / \mathrm{min}])$ and a rake angle $\gamma\left(5^{\circ}\right.$ and $\left.30^{\circ}\right)$. The constant parameters included a milling width $\mathrm{a}_{\mathrm{e}}=14 \mathrm{~mm}$ and a type of material, i.e. magnesium alloy AZ91HP.

The experiments were performed using an AVIA VMC 800HS milling centre. We used two three-tooth carbide milling cutters with different tooth geometry (Fig. 4), dedicated to the machining of magnesium alloys.

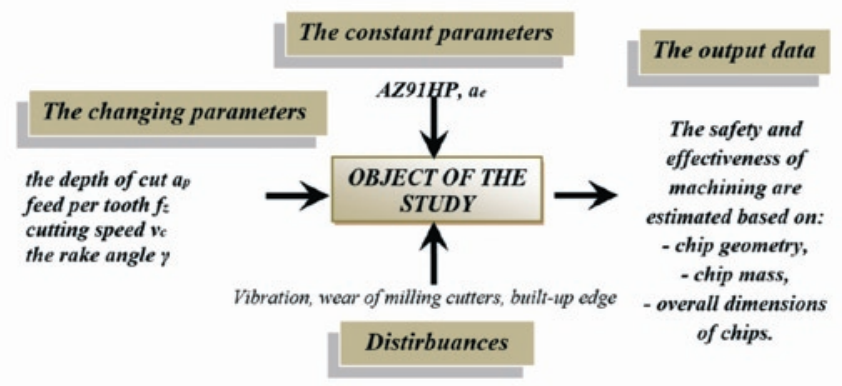

Fig. 3. Plan of investigations into chip geometry, mass and characteristic dimensions depending on changes in variable factors

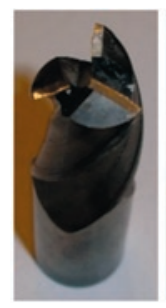

The measurements of length, width and field of chips produced in the milling process were made using a Nikon SMZ1500 optical microscope. The unit mass of chips was measured by a DV215CD laboratory scales with an accuracy of $0.00001 \mathrm{~g}$. The analyzed process was continuous; for every variant, the geometrical characteristics, mass and dimensions of chips were determined based on $5 \div 10$ measurement repetitions.

The objective of the investigations was to examine the shape of
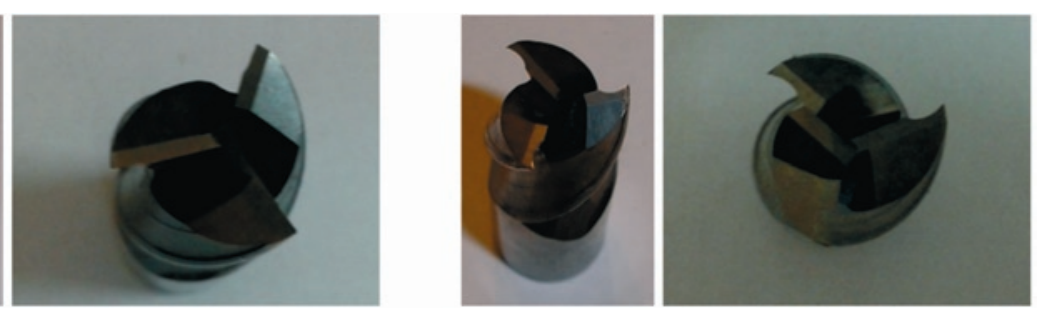

Fig. 4. Three-tooth carbide milling cutter described by an angle of: a) $\gamma=5^{\circ}$, b) $\gamma=30^{\circ}$

chips produced in AZ91HP alloy milling, to determine the degree of fragmentation and unit mass of chips. As for magnesium alloys, the determination of chip shape and regions of dust fraction occurrence is a key problem in the context of selecting operational parameters aimed at minimizing the risk involved in the machining of these alloys.

\section{Results and discussion}

The experiments were performed for specific operational parameters, with chips being collected after each pass of the tool. For the depth of cut set to $a_{p}=0.5 \mathrm{~mm}, a_{p}=1.5 \mathrm{~mm}$ and $a_{p}=3 \mathrm{~mm}$, we used five passes of the tool. Next, for each variable, the chips were divided into fractions depending on their shape and size. Hence, Fraction A comprises the biggest chips, while Fraction D contains the smallest chips. 
a)

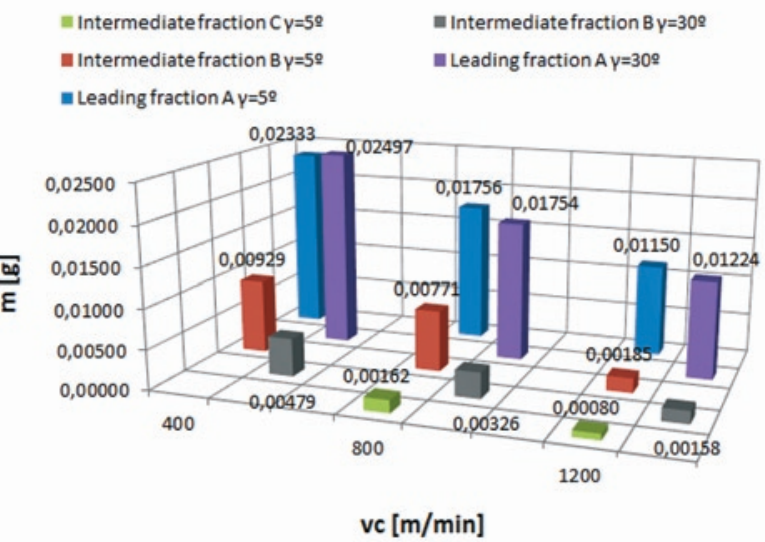

c)
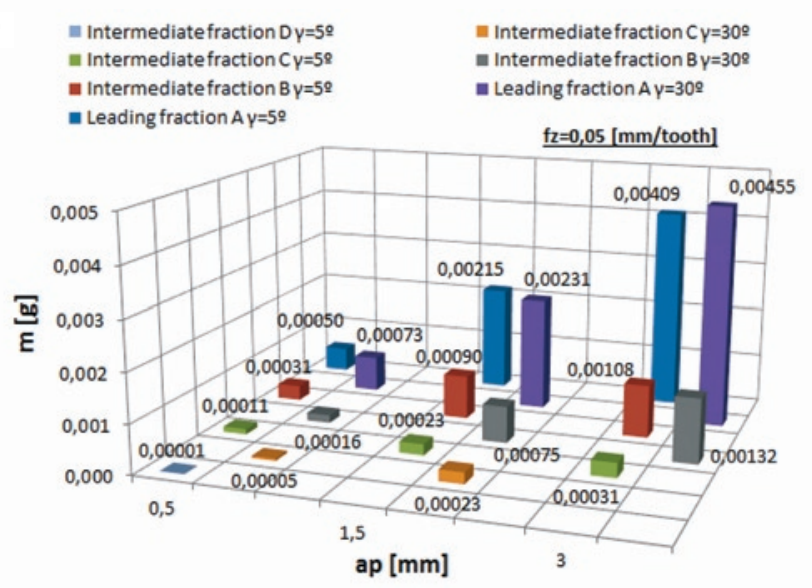

b)
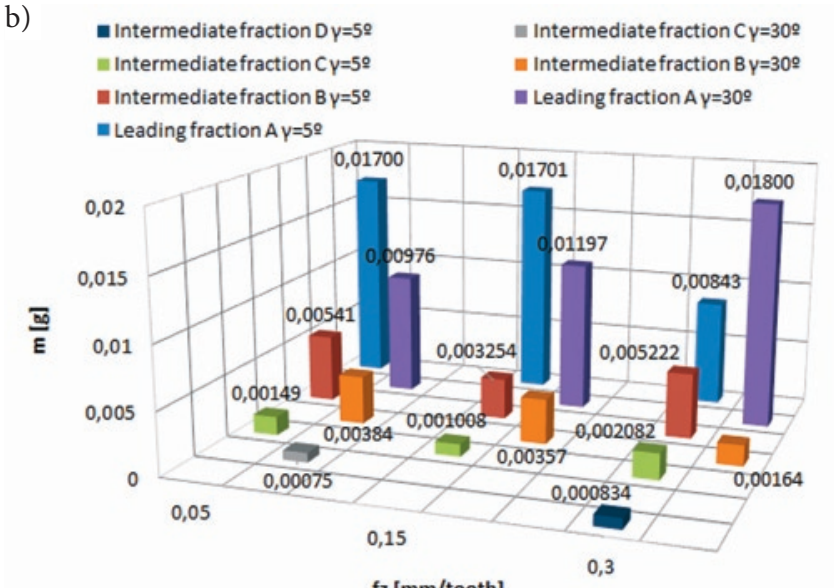

d)

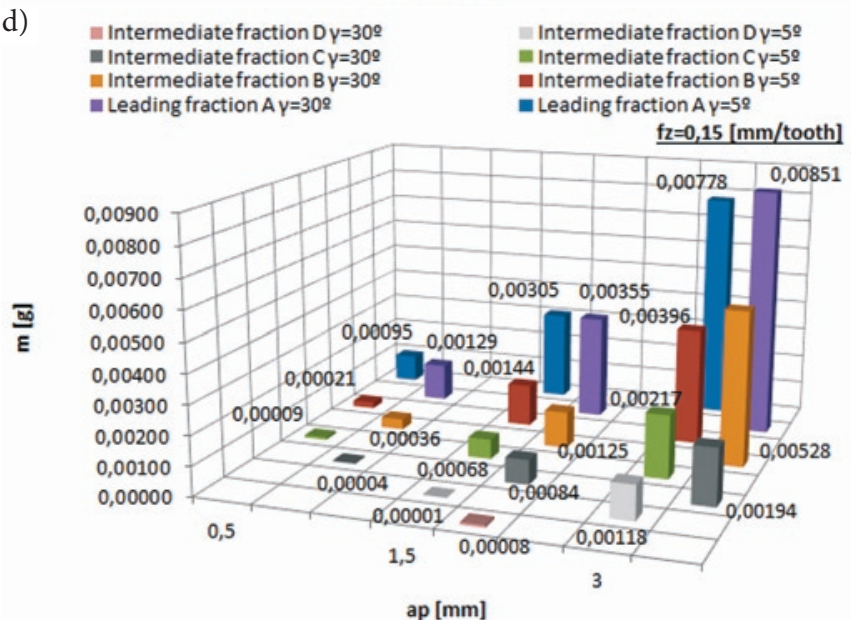

Fig. 5. Effect of changing the operational parameters and tooth geometry on the mass of chips in individual fractions for magnesium alloy AZ91HP: a) $\left.v_{c}, b\right) f_{z}$, c), d) $a_{p}\left(f_{z}=0.05 \mathrm{~mm} /\right.$ tooth, $f_{z}=0.15 \mathrm{~mm} /$ tooth $)$

Fraction A was described as the "leading fraction," while fractions of smaller chips were denoted as "intermediate fractions." We also measured the dimensions of chips assigned to individual fractions and determined the width-to-length ratio for selected chip fractions. Below we give examples of the results of fraction determination.

Table 1 illustrates the effect of the depth of cut $a_{p}$ on both the number of isolated chip fractions and their shape. The greatest number of fractions was isolated at the smallest depth of cut; what is more, Fraction D isolated the smallest depth of cut was described as dust.

To describe phenomena in chip milling, we introduced the following terms:

- fraction, i.e. a population of particles of a specific size or specific dimensions,

- fragmentation, i.e. formation of fractions with different chip shapes and masses, apart from the leading fraction (the biggest and most characteristic one).

The intermediate fraction was defined in two stages: as a fraction with a different shape (compared to that of the leading chip fraction) and as a fraction with a lower mass (in most cases) than approx. 50\% mass of the leading or preceding fraction.

Fig. 5 shows the effect of changing the milling parameters on chip mass and formation of intermediate fractions. The changes in mass of the leading and intermediate chip fractions are presented. The diagrams are given to visualize the effect of selected operational parameters on the examined characteristics of chips.

The data given in Fig. 5a reveal that chips produced at a cutting speed of $400 \mathrm{~m} / \mathrm{min}$ have the highest mass. All isolated fractions reveal a constant relationship involving a decrease in their mass with increasing the cutting speed. Regarding the leading fractions, it can be observed that chip masses for individual values of $\mathrm{v}_{\mathrm{c}}$ were similar despite the application of other tools. According to the data given in Fig. 5b, the masses of the leading fractions for the feed per tooth $\mathrm{f}_{\mathrm{z}}=0.05 \mathrm{~mm} /$ tooth and $\mathrm{f}_{\mathrm{z}}=0.15 \mathrm{~mm} /$ tooth are similar. Differences between the leading fractions can be observed for $\mathrm{f}_{\mathrm{z}}=0.3 \mathrm{~mm} /$ tooth. This is directly related to the differences in chip width: the leading fraction chips produced by the tool described by the angle $\gamma=30^{\circ}$ are much narrower than those created at $\gamma=5^{\circ}$, which has a direct effect on their mass. Figs. $5 \mathrm{c}$ and $5 \mathrm{~d}$, where the cutting speed is changeable, show a gradual increase in mass with increasing depth of cut and feed per tooth, a phenomenon which seems to be obvious given the increase in the section of the machined layer. It is worth drawing attention to intermediate fractions $\mathrm{D}\left(\mathrm{a}_{\mathrm{p}}=0.5 \mathrm{~mm}, \gamma=5^{\circ}\right)$ and $\mathrm{C}\left(\mathrm{a}_{\mathrm{p}}=0.5 \mathrm{~mm}\right.$, $\left.\gamma=30^{\circ}\right)$ shown in Fig. $5 \mathrm{c}$ and to intermediate fractions $\mathrm{C}\left(\mathrm{a}_{\mathrm{p}}=0.5 \mathrm{~mm}\right.$ and $\left.\gamma=5^{\circ}\right), C\left(a_{p}=0.5 \mathrm{~mm}\right.$ and $\left.\gamma=30^{\circ}\right)$ and $\mathrm{D}\left(\mathrm{a}_{\mathrm{p}}=1.5 \mathrm{~mm}\right.$ and $\left.\gamma=5^{\circ}\right)$, D $\left(a_{p}=1.5 \mathrm{~mm}\right.$ and $\left.\gamma=30^{\circ}\right)$ shown in Fig. 5 d. The above fractions were described as dust. Their mass did not exceed $0.0001 \mathrm{~g}$; in the case of Fraction $\mathrm{D}\left(\mathrm{a}_{\mathrm{p}}=0.5 \mathrm{~mm}, \gamma=5^{\circ}\right.$, Fig. $\left.5 \mathrm{c}\right)$ and $\mathrm{D}\left(\mathrm{a}_{\mathrm{p}}=1.5 \mathrm{~mm}\right.$ and $\gamma=5^{\circ}$, Fig. $5 \mathrm{~d})$ the mass was too low $(0.00001 \mathrm{~g})$ to measure even with the aforementioned precise scales.

Fig. 6 illustrates the ratio of chip width to their length for the changeable values of operational parameters $v_{c}, f_{z}$ and $a_{p}$. The figure shows the biggest fraction (leading fraction $\mathrm{A}$ ) and the smallest fraction for the applied parameters. Fig. 6 presenting the quantitative assessment of chips based on their width-to-length ratio reveals some interesting relationships. Analyzing the diagram (Fig. 6a) illustrating the effect of changing the cutting speed, it can be observed that the chips in the leading fractions at $\gamma=30^{\circ}$ were narrower than those at $\gamma=5^{\circ}$. A constant trend can be observed in the case of the smallest 
a)

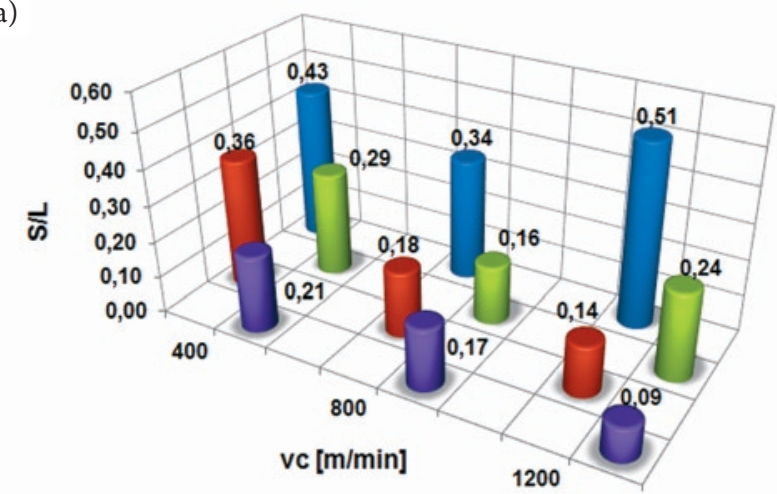

$\square$ Lowest fraction $\mathrm{y}=30^{\circ}$

c)

\begin{abstract}
$\square$ Leading fraction $y=30^{\circ}$
\end{abstract}
- Lowest fraction $y=5^{\circ}$

- Leading fraction $y=5^{\circ}$

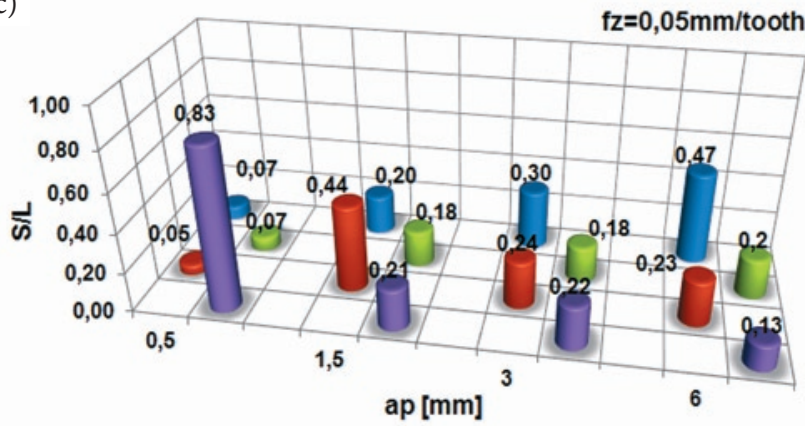

- Lowest fraction $y=30^{\circ}$ $\square$ Leading fraction $y=30^{\circ}$
- Lowest fraction $\mathrm{Y}=5^{\circ}$

$\square$ Leading fraction $y=5^{\circ}$

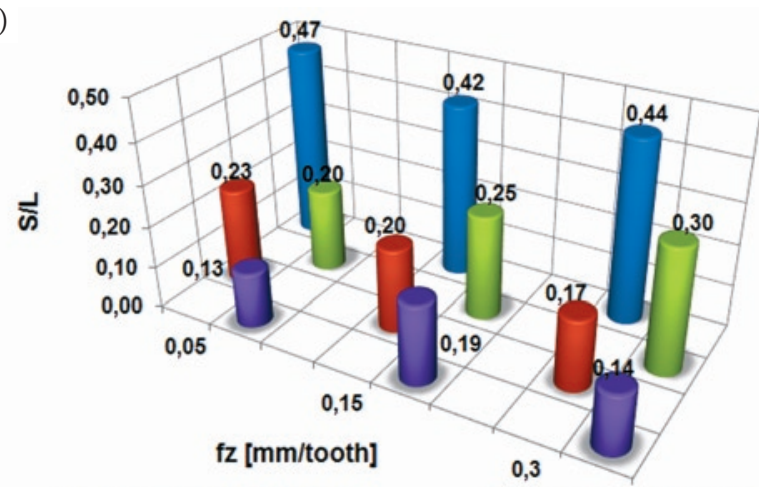

- Lowest fraction $\gamma=30^{\circ}$

- Lowest fraction $y=5^{\circ}$

$\square$ Leading fraction $\gamma=30^{\circ}$ d)

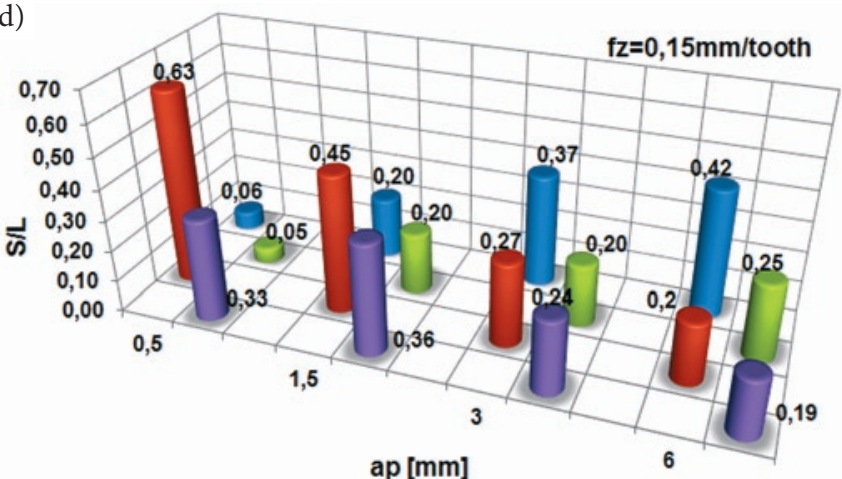

घLowest fraction $y=30^{\circ} \quad \square$ Lowest fraction $y=5^{\circ}$ - Leading fraction $\mathrm{y}=30^{\circ}$

Fig. 6. Ratio of chip width $S$ to length $L$ depending on changes in: a) cutting speed $v_{c}$, b) feed per tooth $f_{z}$, c) depth of cut $a_{p}\left(f_{z}=0.05 \mathrm{~mm} /\right.$ tooth), d) depth of cut $a_{p}$ $\left(f_{z}=0.15 \mathrm{~mm} /\right.$ tooth $)$
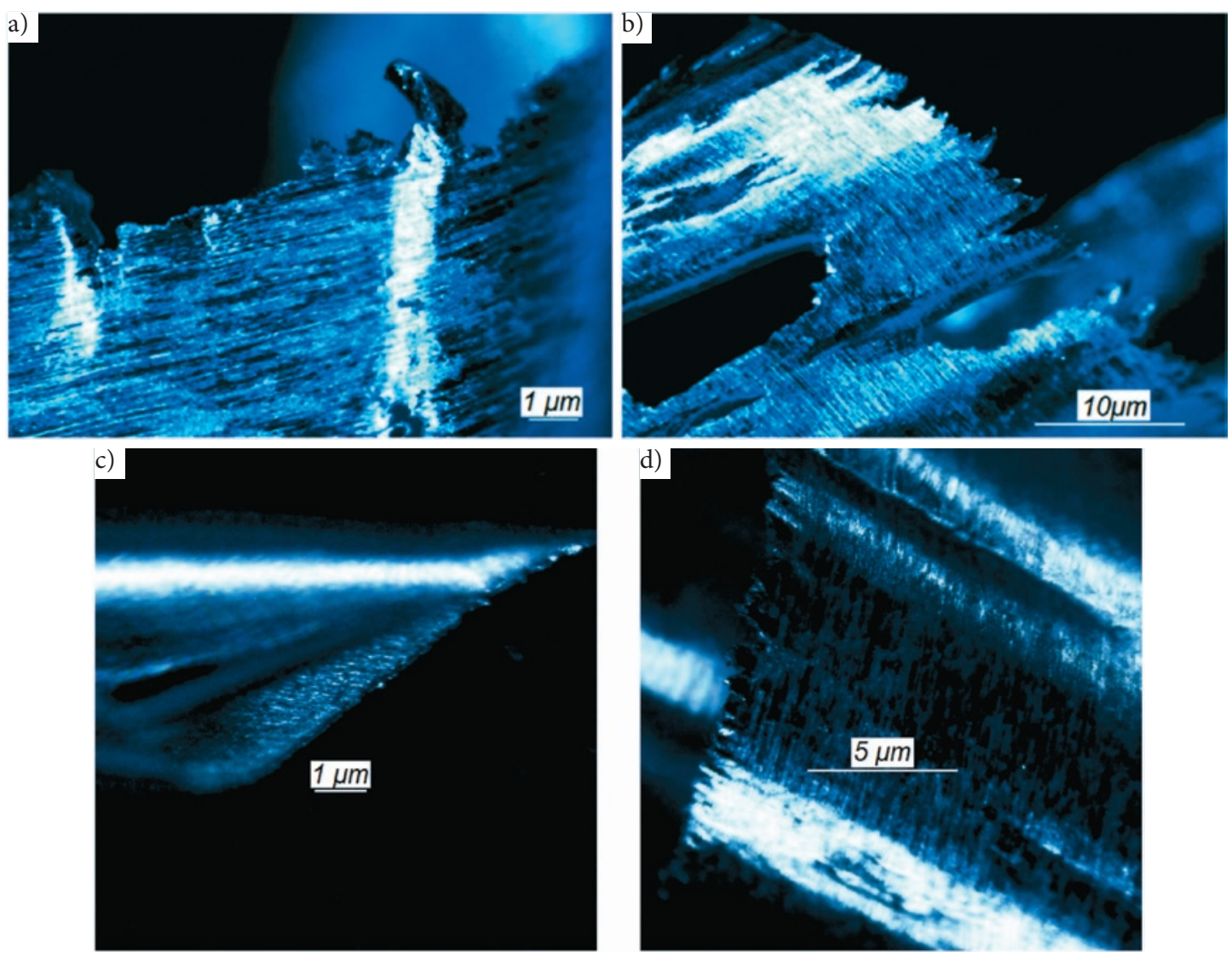

Fig. 7. Analysis of chip partial melting produced in the milling of magnesium alloy AZ91HP using a milling cutter with an angle set to: a) $\gamma=5^{\circ}\left(v_{c}=1200 \mathrm{~m} /\right.$ min, Fraction $B)$, b) $\gamma=5^{\circ}\left(f_{z}=0.3 \mathrm{~mm} /\right.$ tooth, Fraction C), c) $\gamma=30^{\circ}\left(v_{c}=1200 \mathrm{~m} / \mathrm{min}\right.$, Fraction $\left.\left.A\right), d\right) \gamma=30^{\circ}\left(f_{z}=0.3 \mathrm{~mm} /\right.$ tooth, Fraction $\left.B\right)$ 
fractions which become more and more coiled with increasing the cutting speed. Given the variable feed per tooth, it can be observed that the width-to-length ratio of the leading fraction chips produced at $\gamma=5^{\circ}$ remains at the same level, while at $\gamma=30^{\circ}$ - it gradually increases. This ratio decreases for the lowest fractions at $\gamma=5^{\circ}$. The chips of the smallest fraction (for $\gamma=30^{\circ}$ ) produced at $\mathrm{f}_{\mathrm{z}}=0.15 \mathrm{~mm} /$ tooth are only slightly wider than the chips of the smallest fractions produced at other feed per tooth values $\left(\mathrm{f}_{\mathrm{z}}=0.05 \mathrm{~mm} /\right.$ tooth and $\mathrm{f}_{\mathrm{z}}=0.3 \mathrm{~mm} /$ tooth $)$. Another diagram (Fig. 6c) illustrates variations in the depth of cut $a_{p}$ at $f_{z}=0.05 \mathrm{~mm} /$ tooth. At the depth of cut $a_{p}=0.5 \mathrm{~mm}$, the smallest fractions produced two extreme results: 0.05 for $\gamma=5^{\circ}$ and 0.83 for $\gamma=30^{\circ}$. The above two fractions were marked as dust; this significant difference between the results is connected with the form of chips in these fractions. The chips produced with the tool described by the angle $\gamma=5^{\circ}$ has a high length-to-thickness/width ratio, whereas the chips for $\gamma=30^{\circ}$ were fine elements of similar width and length. When $\mathrm{f}_{\mathrm{z}}=0.15 \mathrm{~mm} /$ tooth (Fig. $6 \mathrm{~d}$ ), the width-to-length ratio for the biggest fractions increased with increasing the depth of cut, while for the smallest fractions - it decreased. The small values of the leading fractions obtained at $\mathrm{a}_{\mathrm{p}}=0.5 \mathrm{~mm}\left(0.06\right.$ for $\gamma=5^{\circ}$ and 0.05 for $\left.\gamma=30^{\circ}\right)$ can be attributed to the width of the measured chips - compared to their length, the width was very small. With increasing the depth of cut, the chip width was increasing, too, thereby reducing this dimensional difference.
Fig. 7 shows the analysis of chip partial melting produced in the milling of magnesium alloy AZ91HP. Fig. 7 shows the photographs of chips isolated for the highest cutting speeds and feeds per tooth. The edges of chips produced by milling with an end mill described by $\gamma=30^{\circ}$ are less fuzzy than those produced by an and mill described by $\gamma=5^{\circ}$. However, none of the above photographs reveals the presence of partial meltings which occur at a temperature that is close to the temperature of ignition. For this reason, it can be concluded that the temperature in the chip formation zone was much lower than ignition temperature. This means that machines can be safely operated under dry machining conditions even in HSC.

Figs. 8 and 9 summarize the results of research on chip fragmentation in the machining of magnesium alloy AZ91HP. The regions prone to the formation of a dust fraction are marked in red.

Both Fig. 8 and Fig. 9 demonstrate that dust fractions are most likely to occur at the smallest depths of cut $\mathrm{a}_{\mathrm{p}}=0.5 \mathrm{~mm}$ and $\mathrm{a}_{\mathrm{p}}=1.5 \mathrm{~mm}$. The application of these parameters generated the highest number of dust fractions. The smallest degree of fragmentation was affected by cutting speed and feed per tooth, while the use of the tool described by the rake angle $\gamma=30^{\circ}$ led to the production of fewer numbers of fractions.

\section{Summary and conclusions}

The results of chip fragmentation demonstrate that a lower number of isolated fractions, hence a smaller degree of chip fragmentation are produced by the tool described by the rake angle $\gamma=30^{\circ}$. Moreover, the largest number of chip fractions are isolated when the depth of cut $a_{p}$ is changed, while the smallest number of fractions are isolated when the cutting speed $\mathrm{v}_{\mathrm{c}}$ is changed. In terms of chip size, the lengths of all leading fractions are similar on changing the above parameters; more significant differences can be observed with respect to chip width. The width of leading chip fractions produced with the tool described by the rake angle $\gamma=5^{\circ}$ is higher than those of the chips produced at $\gamma=30^{\circ}$ for all variables $\left(\mathrm{v}_{\mathrm{c}}\right.$, $\left.f_{z}, a_{p}\right)$.

The main objective of the investigation was to determine regions in the space of independent variables that are undesired due to the highest concentration of dust fraction. These regions include the lowest depths of cut $\left(\mathrm{a}_{\mathrm{p}}=0.5 \mathrm{~mm}\right.$ and $\left.\mathrm{a}_{\mathrm{p}}=1.5 \mathrm{~mm}\right)$. Examining the shape of the obtained chips, it can be observed that the chips produced at the depth of cut $a_{p}=6 \mathrm{~mm}$, feed per tooth $\mathrm{f}_{\mathrm{z}}=0.15 \mathrm{~mm} /$ tooth and two cutting speeds $\mathrm{v}_{\mathrm{c}}: 400 \mathrm{~m} / \mathrm{min}$ and $800 \mathrm{~m} / \mathrm{min}$, are the most desired in terms of ease of their storage and removal from the machine's working space.

The results have led to the formulation of the following general conclusions with respect to AZ91HP alloy milling:

from the point of view of milling machine operation, effective (reliable) and safe (failure-free) dry milling treatment of magnesium alloys is a viable process,

Fig. 9. Degree of chip fragmentation depending on changes in operational parameters $v_{c}, f_{z}$, $a_{p}$ for the milling cutter with an angle $\gamma=30^{\circ}$ 
- the desired machining regions are those where magnesium dust does not occur,

- for operational reasons, it is recommended to avoid both small values of $a_{p}$ and of $\gamma$,

- operational parameters which do not lead to damage of the technological machines are contained in the following range: $\mathrm{v}_{\mathrm{c}}=400 \div 800 \mathrm{~m} / \mathrm{min}, \mathrm{f}_{\mathrm{z}}=0.15 \div 0.3 \mathrm{~mm} /$ tooth and $\mathrm{a}_{\mathrm{p}} \geq 1.5 \mathrm{~mm}$.

The operational parameters of the machining process run under specific conditions can be changed within a certain range of techno- logical variables. It should also be underlined that safe and reliable operation of technological machines in the machining of magnesium alloys is also strongly related to a general culture of machine tool maintenance.

\section{Acknowledgement}

Financial support of Structural Funds in the Innovative Economy Operational Programme (IE OP) financed from the European Regional Development Fund, No. POIG.01.01.02-00-015/08-00, is gratefully acknowledged.

\section{References}

1. Akyuz B. Machinability of magnesium and its alloys. TOJSAT: The Online Journal of Science and Technology 2011; 1(3): 31-38.

2. Arai M, Sato S, Ogawa M, Shikata H I. Chip Control in Finish Cutting of Magnesium Alloy. Journal of Materials Processing Technology 1996; 62: 341-344, http://dx.doi.org/10.1016/S0924-0136(96)02432-6.

3. Fang F Z, Lee L C, Liu X D. Mean Flank Temperature Measurement in High Speed Dry Cutting. Journal of Materials Processing Technology 2005; 167: 119-123, http://dx.doi.org/10.1016/j.jmatprotec.2004.10.002.

4. Guo Y B, Salahshoor M. Process mechanics and surface integrity by high-speed dry milling of biodegradable magnesium-calcium implant alloys. CIRP Annals - Manufacturing Technology 2010; 59: 151-154, http://dx.doi.org/10.1016/j.cirp.2010.03.051.

5. Hou J Z, Zhou W, Zhao N. Methods for Prevention of Ignition during Machining of Magnesium Alloys. Key Engineering Materials 2010; 447-448: 150-154, http://dx.doi.org/10.4028/www.scientific.net/KEM.447-448.150.

6. Krolczyk G., Legutko S. Investigations Into Surface Integrity in the Turning Process of Duplex Stainless Steel. Transactions of FAMENA 2014; 38: 77-82.

7. Krolczyk G., Legutko S., Nieslony P., Gajek M. Study of the surface integrity microhardness of austenitic stainless steel after turning. Tehnički Vjesnik - Technical Gazette 2014; 21: 1307-1311.

8. Krolczyk G., Nieslony P., Legutko S., Stoic A. Microhardness changes gradient of the Duplex Stainless Steel (DSS) surface layer after dry turning. Metalurgija 2014; 53: 529-532.

9. Kuczmaszewski J, Pieśko P. Wear of milling cutters resulting from high silicon aluminium alloy cast AlSi21CuNi machining. Eksploatacja i Niezawodnosc - Maintenance and Reliability 2012; 16(1): 37-41.

10. Kuczmaszewski J, Zagórski I. Badania fragmentowania wiórów w procesie frezowania stopów magnezu. Mechanik 2014; 8-9: 321-328.

11. Le Coz G, Marinescu M, Devillez A, Dudzinski D, Velnom L. Measuring temperature of rotating cutting tools: Application to MQL drilling and dry milling of aerospace alloys. Applied Thermal Engineering 2012; 36: 434-441, http://dx.doi.org/10.1016/j.applthermaleng.2011.10.060.

12. Legutko S. Development trends in machines operation maintenance. Eksploatacja i Niezawodnosc - Maintenance and Reliability 2009; 2: 8-16.

13. Legutko S. Podstawy eksploatacji maszyn i urządzeń. Warszawa: Wyd. Szkolne i Pedagogiczne, 2007.

14. Li H Z, Liu K, Li X P. A new method for determining the undeformed chip thickness in milling. Journal of Materials Processing Technology 2001; 113(1-3): 378-384, http://dx.doi.org/10.1016/S0924-0136(01)00586-6.

15. Lotfi Sai, Bouzid W, Zghal A. Chip thickness analysis for different tool motions for adaptive feed rate. Journal of Materials Processing Technology 2008; 204(1-3): 213-220, http://dx.doi.org/10.1016/j.jmatprotec.2007.11.094.

16. Oczoś K E. Extension of the magnesium alloys application range. Mechanik 2009; 5-6: 386-400.

17. Oczoś K E, Kawalec A. Kształtowanie metali lekkich. Warszawa: PWN, 2012.

18. Oziemski S. Efektywność eksploatacji maszyn, Podstawy techniczno-ekonomiczne. Radom: Wyd. Instytutu Technologii Eksploatacji, 1999.

19. Semotiuk L. An analysis of the operational characteristics of innovative tool structures used in high speed rough milling processes. Eksploatacja i Niezawodnosc - Maintenance and Reliability 2009; 1: 46-53.

20. Wojciechowski S., Twardowski P., Wieczorowski M. Surface texture analysis after ball end milling with various surface inclination of hardened steel. Metrology and Measurement Systems 2014; 21(1): 145-56, http://dx.doi.org/10.2478/mms-2014-0014.

21. Zhao N, Hou J, Zhu S. Chip ignition in research on high-speed face milling AM50A magnesium alloy. Second International Conference on Mechanic Automation and Control Engineering 15-17 July 2011; Inner Mongolia, China, http://dx.doi.org/10.1109/MACE.2011.5987127.

22. POLSKA NORMA Badanie trwałości noży tokarskich punktowych. PN-ISO 3685:1996.

23. http://www.polmag.pl/, z dnia 20.03.2015r.

\section{Olga GZIUT \\ Józef KUCZMASZEWSKI \\ Ireneusz ZAGÓRSKI}

Lublin University of Technology

Mechanical Engineering Faculty

Department of Production Engineering

ul. Nadbystrzycka 36, 20-618 Lublin, Poland

E-mail: j.kuczmaszewski@pollub.pl, i.zagorski@pollub.pl 